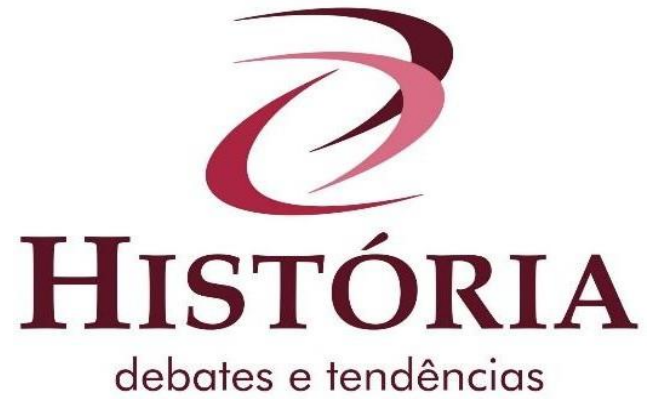

\title{
O PRÍNCIPE DE MAQUIAVEL COMO FONTE HISTÓRICA
}

\section{THE PRINCE OF MACHIAVELLI AS A HISTORICAL SOURCE}

\section{EL PRÍNCIPE DE MAQUIAVELO COMO FUENTE HISTÓRICA}

\author{
José Costa D'Assunção Barros ${ }^{i}$
}

\begin{abstract}
Resumo: O artigo busca discutir o livro O Príncipe, de Nicolau Maquiavel, analisando seus potenciais para tratamento historiográfico, Neste sentido, parte-se de um empenho de compreensão do lugar de produção da fonte O Príncipe - discutindo os aspectos sociais, culturais e identitários que envolvem seu autor, as circunstâncias de sua produção, a sociedade e mundo político no interior dos quais surge essa obra de realismo político. A Intertextualidade, considerada fundamental para a compreensão de O Príncipe como fonte histórica, expressa-se na contraposição desta obra ao circuito de textos conhecidos como 'espelhos de príncipes'. $\mathrm{Na}$ metade final do artigo, evocamos diversos problemas historiográficos que podem ser aplicados ao Príncipe para a sua inserção em uma perspectiva de História-Problema.
\end{abstract}

Palavras-Chave: O Príncipe; Maquiavel; Política; Fonte Histórica; Lugar de Produção.

\begin{abstract}
The article seeks to discuss the book The Prince, of Nicolau Machiavelli , analyzing its potentials for historiographic treatment. In this sense, we start from an effort to understand the place of production of The Prince - discussing the social, cultural and identity aspects which involve its author, the circumstances of its production, the society and political world where this work of political realism has arised. The intertextuality, considered fundamental to the understanding of The Prince as a historical source, is expressed in the opposition of this work to the circuit of texts known as "mirrors of princes". In the final half of the article, we evoke several historiographical problems that can be applied to the Prince, completing the possibility of his insertion in a perspective of ProblemHistory.
\end{abstract}

Keywords: The Prince; Machiavelli; Politics; Historical Source; Production's Place

Resumen: El artículo busca discutir el libro El Príncipe, de Nicolau Machiavelli, analizando sus potenciales para el tratamiento historiográfico. En este sentido, partimos de un esfuerzo por comprender el lugar de producción de la fuente El Príncipe, discutiendo los aspectos sociales, culturales y de identidad. que afectan su autor, las circunstancias de su producción, la sociedad y el mundo político dentro del cual surge este trabajo de realismo político. La 
intertextualidad, considerada fundamental para la comprensión dos potenciales de $E l$ Príncipe como fuente histórica, se expresa en la oposición de esta obra al circuito de textos conocidos como "espejos de príncipes". En la mitad final del artículo, evocamos varios problemas historiográficos que pueden aplicarse al Príncipe para su inserción en una perspectiva de Historia-Problema

Palabras-clave: El principe; Maquiavelo; Política; Fuente histórica; Lugar de producción.

\section{O PRÍNCIPE DE MAQUIAVEL COMO FONTE HISTÓRICA}

\section{$O$ Príncipe de Maquiavel: sua época e seu lugar de produção}

Neste artigo, nossa intenção será a de discutir as potencialidades da obra $O$ Príncipe, de autoria de Maquiavel, como fonte histórica para compreender aspectos de sua época, contexto e circunstâncias de sua produção, bem como abordar problemas historiográficos diversos. Antes de analisar o lugar de produção deste tão bem conhecido manual político renascentista que é $O$ Príncipe, de Nicolau Maquiavel (1469-1527), é oportuno lembrar que esta obra é frequentemente examinada pelos cientistas políticos sob uma outra perspectiva, que não a historiográfica (habitualmente situando Maquiavel como um autor que dialoga sobre a política em sua dimensão realista, ao lado de outros de épocas diversas e inclusive dos tempos contemporâneos).

Ao longo da história, os políticos profissionais e práticos também têm lido com frequência $O$ Príncipe, e muitos tiveram esta obra escrita em 1513 até mesmo como um livro de cabeceira pronto a lhe oferecer conselhos para lidar com o mundo político de suas próprias épocas e como base para interagir com a sociedade sob a perspectiva do poder e da estratégia de ação política. Napoleão Bonaparte (1769-1821), por exemplo, era um leitor recorrente de $O$ Príncipe, e seu exemplar pessoal com anotações nas margens do livro chegou mesmo a ser publicado posteriormente (em 1816), transformando-se hoje em fonte histórica com duplo lugar de produção: o da própria obra no século XVI, e o de suas anotações no século XIX. Políticos e militares os mais diversos, e homens de negócios, têm recorrido ao Príncipe de Maquiavel como a um livro com o qual podem dialogar acerca de como obter e conservar o poder, como agir com seus comandados e subalternos, como tratar as massas e se prevenir contra suas possibilidades de comportamentos, ou como agir perante os aliados e adversários políticos ou com os concorrentes em sua área de atuação.

De nossa parte, contudo, a ideia é pensar e discutir $O$ Príncipe de Maquiavel como fonte histórica, pois para os historiadores é isso o que esta obra principalmente é. A escolha desta obra muito conhecida nos permitirá verificar aspectos que consideramos importantes 
para se pensar quando temos diante de nós uma fonte histórica textual ou de qualquer outro tipo - neste caso específico, uma fonte autoral, escrita por um indivíduo que assina a sua própria obra. A análise poderá contribuir para ilustrar uma linha de ação que pode ser aplicada à análise de outros textos com seus autores, sejam eles escritores de obras em qualquer campo científico, profissional ou literário, sejam autores de textos privados como diários, cartas e de outros tipos. Que perguntas podemos fazer acerca de um autor? O que indagar sobre as circunstâncias em que escreveu sua obra, sobre a inserção de sua obra em sua própria época e sociedade, e sobre sua posição diante de uma finalidade ou públicoleitor a atingir? Como pensar, enfim, uma obra autoral do passado, distante ou recente no tempo que seja, como uma fonte histórica que apresenta um 'lugar de produção' a ser compreendido no próprio ato da operação historiográfica?

Devemos compreender, de saída, que o autor de uma obra como O Príncipe (como todos os autores) está sempre situado no intercurso de uma série de linhas de forças. Pensemos em um primeiro aspecto, a possibilidade de compreender Maquiavel e esta obra específica em uma certa 'unidade de época'. A data de produção obra é bem conhecida: 1513, e também o seu lugar geopolítico de produção: a República de Florençaii. Por outro lado, como livro que é disponibilizado em mais ampla circulação, a primeira data de publicação é 1532. Mas disto falaremos depois. Por ora, para situar Maquiavel em uma unidade de época adequada, devemos considerar, antes de tudo o mais, que Maquiavel é um homem da Itália Renascentista. De fato, a cultura renascentista contribui com certo repertório de possibilidades discursivas para qualquer escritor de seu tempo, e isso não foi diferente com Maquiavel.

Os humanistas italianos acreditavam, por exemplo, estar vivendo um grande despertar cultural que atribuíam à redescoberta da Antiguidade. Nesta mesma operação, costumavam depreciar a Idade Média como uma "longa noite de mil anos", ou como uma "idade das trevas", ou ao menos como um período predisposto a mistificações e a uma supervalorização do outro mundo - uma idade da fé extremada que estava interposta entre dois períodos que valorizavam a razão e traziam centralidade à experiência humana neste mundo. Os renascentistas sintonizavam-se intertextualmente com os grandes nomes da Antiguidade Greco-Romana. Consideravam-se humanistas e valorizadores da Razão, uma imagem que bem mais tarde, no século XVIII, seria retomada mais uma vez pelos filósofos iluministas. Esta imagem que os artistas e intelectuais renascentistas produziam acerca de si mesmos interfere naturalmente na produção de seus discursos, nos modelos a partir dos quais pretendiam construir a sua "modernidade" por oposição a uma Idade Média que 
julgavam obscura. A inspiração nos modelos gregos e romanos da chamada "antiguidade clássica" é clara entre os renascentistas, incluindo Maquiavel - um autor que, por ser italiano, costumava se inspirar especialmente nos romanos. É assim que, da lavra de Maquiavel e do mesmo período de produção de O Príncipe (1513) temos os Discursos sobre a primeira década de Tito Lívio (1513-1521); da mesma forma, o modelo para a sua Arte da Guerra (1520) será o exército romano - cenas do inevitável e contumaz diálogo de um homem Renascentista com os antigos que tanto admirava.

O lugar de produção de diversas das obras de Maquiavel, portanto, pode ser enquadrado na modernidade renascentista, mas ao mesmo tempo sofre ressonâncias de outra época: a chamada antiguidade clássica. Este diálogo também transparece em $O$ Príncipe. Quando divide as formas de organização do Estado em principados e repúblicas - e estas últimas nas possibilidades da forma aristocrática (uma minoria de governantes subordina uma maioria de governados), democracia restrita (quando se dá o contrário) ou democracia ampla (a coletividade se autogoverna) - Maquiavel vai buscar seus modelos comparativos em Esparta e Atenas para os primeiros casos, e na Roma posterior à instituição dos tribunos da plebe, para o últimoiii. Quando reflete sobre o "herói fundador de estados", Rômulo é o exemplo evocado. Ou seja, independente das ideias que está discutindo, os exemplares de Nicolau Maquiavel são frequentemente selecionados e recolhidos da Antiguidade GrecoRomana. É, aliás, com os modelos de heróis da Antiguidade que Maquiavel põe em diálogo o seu herói moderno, inspirado em César Bórgia (1475-1507). Para além disto, O Príncipe oferece um diálogo entre o 'mundo moderno', do qual Maquiavel teve a experiência direta da prática política, e os autores antigos, estudados pelo autor. Há uma passagem deliciosa da carta de Maquiavel a Francisco Vettori - na ocasião mesma em que ele anuncia a este correspondente que havia acabado de concluir O Príncipe - na qual ele expressa de maneira irretocável esta sintonia de um humanista renascentista com os espíritos clássicos antigos:

À noite, de regresso à casa, adentro no meu escritório; e, à porta, dispo minhas roupas cotidianas, sujas de barro e lama, envergo as roupas de corte ou cerimônia e, vestido com decoro, entro na antiga convivência dos homens do passado; acolhido por eles, bondosamente, nutro-me daquele alimento que é o único a mim apropriado e para o qual nasci. Não me causa vergonha falar com eles, e lhes indago as razões de suas ações, e eles humanamente me respondem; e por quatro horas não sinto nenhum aborrecimento, esqueço todos os desgostos, não temo a pobreza, não me perturba a morte: transfundo-me neles inteiramente" (MAQUIAVEL, 2000, p.182 ) iv. 
Poderíamos seguir avançando no esclarecimento sobre a contribuição das ideias renascentistas mais amplas - a nova visão do ser humano e do mundo, a emergência do indivíduo, ou tantas outras - na obra de Maquiavel. Mas saltaremos para um segundo interferente: o fato de que, antes (ou depois) de ser um homem renascentista, Maquiavel era um florentino do início do século XVI. A Florença era então um pequeno e conturbado estado, em delicada posição no jogo de xadrez das relações internacionais. De um lado, a península Itálica - com suas pequenas potências independentes - tinha de se confrontar com o quadro continental de uma Europa dominada por monarquias que haviam se beneficiado de um peculiar centralismo político que emergira das antigas fragmentações feudais em países como Portugal, Espanha, França e Inglaterra. Por outro lado, havia a rede de potências italianas concorrentes, na qual se sobressaíam a República Florentina, a República de Veneza, o Ducado de Milão, O Reino de Nápoles e os Estados Papais. Economicamente, as cidades italianas já eram bem menos atuantes do que um dia haviam sido com sua bem urdida prática comercialv. Frente aos grandes poderes estatais centralizados que vigoram no continente europeu, e península itálica apresenta-se relativamente desarmada nos planos político e militar, particularmente em decorrência do anacronismo de sua organização em cidades-estados e da ausência de uma liderança central. A reflexão sobre o 'poder central' - precisamente o que faltava na Itália de seu tempo quando contrastada com as monarquias centralizadas do continente europeu - e sobre a 'conservação do poder', no momento mesmo em que o autor perdera a sua influência e poder político, surgem como temas importantes de $O$ Príncipe. Os elementos até aqui apresentados apresentam-se como linhas de força importantes na constituição do lugar de produção de $O$ Príncipe. Temos um autor, com suas especificidades e traços biográficos, e temos uma época - demarcada pela modernidade renascentista e pelo xadrez externo definido pela emergência de monarquias centralizadas na Europa. Ainda sobre o lugar de produção mais amplo, é oportuno lembrar que a ‘era dos impressos’ já começara, e os livros já contavam com maior possibilidade de circulação.

O xadrez interno das rivalidades econômicas e políticas entre as cidades italianas é outra linha de força bem presente. Torna-se oportuno lembrar que estes dois jogos de xadrez - o externo e o interno - dialogam entre si: no quadro de rivalidades e enfrentamentos bélicos entre as cidades italianas, e nas disputas pela governança em cada uma destes pequenos principados, as monarquias fortemente centralizadas do continente europeu podiam intervir, dando proteção a umas cidades contra outras, favorecendo a ascensão desta ou daquela família ao poder em determinada cidade, e assim por diante em um jogo de 
pressões diversas que podiam incluir mesmo invasões militares. Dada a posição geográfica da Itália no continente, as intervenções mais frequentes vinham da Espanha e da França. A interferência espanhola, por exemplo, esteve diretamente envolvida na destruição do governo republicano de Soderini e na ascensão ao poder da família Médici. O pretexto dos espanhóis para o adentramento militar na península havia sido a sua própria luta externa contra os franceses, que haviam ocupado a região de Milão. Os Médici já haviam governado a cidade, e agora retornavam ${ }^{\text {vi }}$. Para isso também haviam tido o apoio eclesiástico de um dos seus familiares, o cardeal João de Médici (1475-1521), que se tornaria o papa Leão X a partir de 1513 (data, aliás, da própria escrita de O Príncipe)vii. A estrutura econômica também estava explicitamente imbricada na estrutura política nesta sociedade, pois desde 1328 havia um sistema eleitoral elaborado para assegurar a rotatividade do governo republicano de Florença que se baseava em uma representatividade assimétrica das guildas (corporações de ofícios), matizada pelo prestígio que era conferido pela sociedade às atividades por exercidas pelas sete 'guildas maiores' em contraste com as quatorze 'guildas menores'viii.

\section{A dimensão da autoria}

Refletamos sobre outro interferente que afeta a produção da obra: o plano individual do autor - sua posição social e política, sua atividade profissional e, ademais, o lugar mais específico de onde ele agora produz o seu discurso: não mais o do poder políticoadministrativo que exercera no momento anterior de sua vida, mas o do cárcere privado. Este último aspecto, aliás, remete ao que podemos considerar como 'circunstâncias de produção' da obra. É oportuno observar que essas circunstâncias - de acordo com as quais Maquiavel havia sido preso em decorrência da vitória, em Florença, de um poder principesco que derrubara o poder republicano ao qual o autor florentino se integrara por tanto tempo - confrontam-se com a posição republicana que Maquiavel sempre teve e continuaria a ter, apesar do seu investimento no Príncipe - livro que discorre sobre o poder principesco $^{\text {ix }}$. O ano de 1512, como dissemos, é assinalado por uma troca de poder que demarca o retorno dos Médici a Florença, o que destitui Maquiavel de suas posições na administração pública e na política florentina ${ }^{x}$. Em 1513 ele é exilado em sua propriedade particular em San Casciano, e é dali que começa a escrever $O$ Príncipe. Sua nova posição no universo social e político, e suas circunstâncias naquele momento, incidirão sobre os objetivos e metas do autor ao escrever sua nova obra: alguns são objetivos declarados, outros 
ocultos e inconfessáveis, e outros derivados da reflexão sobre a prática política que desenvolvera durante toda a sua vida.

A dedicatória de 1515 a Lourenço II, potentado da família dos Médicis e novo soberano, parece trair o objetivo mais superficial de reconquistar os favores da família que reassumira o poderxi. O Príncipe pode ser entendido como um manual de prática política. Maquiavel aponta como receptor de seu discurso o governante, para cuja educação política contribuiria sua obra. Mas Rousseau levanta três séculos mais tarde uma interessante hipótese, que mais adiante discutiremos em maior nível de profundidade: ao simular dar lições aos governantes (que rigorosamente delas não precisavam), Maquiavel na verdade as dava ao povo - tornando claros os mecanismos de funcionamento do poder e desmistificando a prática política para uma população mais ampla que não a conhecia. Ou seja, por trás do receptor declarado, talvez estivesse escondido outro receptor bem mais amplo. Cada um destes receptores, naturalmente, é antecipado pelo autor (lembrando a máxima de que "o receptor sempre se inscreve antecipadamente na produção de uma obra").

Denis Diderot (1713-1784), na mesma época de Rousseau, também aborda o texto maquiaveliano sob a perspectiva da inversão, produzindo uma leitura do Príncipe como uma sátira que se esconde sob a capa do elogio. E por aí se multiplicam as leituras possíveis de $O$ Príncipe, às quais poderíamos acrescentar que Maquiavel também escrevia a sua obra para si mesmo, na medida em que ela foi produto de uma reflexão e prática de toda uma vida, além de refletir simultaneamente um momento de desânimo diante de sua exclusão do poder e a sua tentativa de superar esta situação. Poderíamos nos perguntar qual a leitura mais apropriada de $O$ Príncipe. Talvez todas elas, já que o momento de produção de uma obra interage frequentemente com uma multiplicidade de objetivos, muitos dos quais não assumidos pelo autor ou até dele desconhecidos. À parte sua posição sociopolítica e circunstancial, um autor também tem, como vimos, uma posição teórico-metodológica, a partir da qual pode defender tais e quais ideias contra outras posições, e também preconizar certos modos de agir e de fazer as coisas. Ao lado disso, nenhum texto está isolado de outros de sua época e dos que o precederam, e para compreendê-lo é preciso decifrar o diálogo que o autor trava com outros autores, outras visões de mundo, outros posicionamentos filosóficos, éticos, práticos.

A reflexão política de Maquiavel pretende ser realista e pragmática: sua intenção é dizer algo que se revele de utilidade prática para o leitor. Suas propostas ensejam uma ética que visa produzir resultados. A partir destes parâmetros, pensados a partir de uma realidade política efetiva e de uma prática humana concreta, ele trava um diálogo contra toda uma 
tradição de especulação filosófica que havia estudado o Estado como um tipo ideal desvinculado das instituições concretas. Entre os nomes que permeiam esta especulação mais idealista sobre o poder, podemos citar Aristóteles, Platão, e mesmo contemporâneos como Erasmo de Rotterdam e Thomas More, que também construíram modelos do bom governante mas a partir de um humanismo abstrato. Deste modo, mesmo sendo um humanista renascentista, Maquiavel não deixava de se opor dialogicamente aos humanistas tradicionais que se limitavam a admirar a Antiguidade sem fazê-la interagir com o mundo moderno. Além disto, $O$ Príncipe também é fundado a partir de uma visão cíclica da História, o que implica na possibilidade de aprender com o passado para conduzir a vida presente. Tal perspectiva, própria de Maquiavel, já vinha por outro lado de uma extensa contribuição de antigos filósofos, como Cícero, que propunham a ideia de que "a História é a Mestra da Vida".

Seria oportuno pensar como poderia ser esboçado um 'acorde de identidades' para Maquiavel. Como ele via a si mesmo? Certamente o humanismo era um traço forte de sua identidade. Maquiavel não era somente o que hoje classificaríamos como um cientista político. Sua formação e prática humanista, muito comum em outros indivíduos de sua posição social na Itália de sua época, o levava a ter ambições culturais mais amplas. Não desejava interferir na sociedade apenas através de ensaios, como autor, ou de sua atuação pragmática como político, mas também através de outras formas de expressão cultural. Sua comédia Mandrágora é considerada uma obra prima da dramaturgia da Itália renascentista, e através dela Maquiavel procede a uma impiedosa sátira contra a corrupção de sua sociedade ${ }^{x i}$. Sua contribuição como historiador também é particularmente importante. Certamente que Maquiavel via a si mesmo como um político experimentado, capaz de compreender a verdadeira natureza do poder. Uma nota intensa de 'realismo' - que nele se produz por oposição à concepção idealista de muitos dos que escreviam sobre a Política em sua época - era outro traço importante de sua identidade.

\section{As Intertextualidades}

Quero conduzir esta reflexão sobre o lugar de produção de $O$ Príncipe para uma questão fundamental. Ainda que produzido por um autor - o qual se encontra no interior de uma época, de um lugar, de uma sociedade e sujeito a certas circunstâncias - já vimos que nenhum texto existe isoladamente de outros textos. Chamamos às diversas conexões de um 
texto com outros textos de intertextualidades. Já de saída, um texto dialoga com outros a partir do gênero ao qual pertence, e este gênero pode apresentar uma longa história. Um poeta escreve sua realização literária em versos que se sucedem e se agrupam em estrofes, e que permitem práticas de escrita que valorizam a sonoridade das palavras, seu potencial imagético, o jogo das emoções, e possibilidades específicas como a da rima ou das ressonâncias entre as palavras - porque antes deles inúmeros outros poetas já escreveram este tipo de texto, que terminou por configurar um gênero textual que chamamos de poesia. As cartas - gênero textual que estabelece uma comunicação entre dois interlocutores também apresenta uma forma predominante, certas fórmulas expressivas recorrentes, determinadas práticas como a datação e assinatura, certos modos de saudar o interlocutor e de dele se despedir. Um autor, ao escrever uma carta, está configurando sua escrita a um gênero textual que foi percorrido por inúmeros outros autores, antes dele. Lembro, neste momento, que a Intertextualidade também contribui para configurar o lugar de produção de um texto. A partir desta observação, podemos nos perguntar agora a que gênero de texto pertence $O$ Príncipe, e com que textos dialoga.

Foi bem conhecido na Idade Média europeia, e além desta época, o gênero textual que foi denominado 'Espelho de Príncipe'. Podemos inserir O Príncipe nesta família textual, ainda que Maquiavel elabore um espelho de príncipe politicamente realista, em contraposição aos espelhos de príncipe idealistas que eram tão comuns na Idade Média e mesmo no período moderno. Da reflexão sobre o que é um 'espelho de príncipe', poderemos extrair novos elementos para entender o lugar de produção desta obra, pois podemos dizer que ela simultaneamente se insere neste gênero com relação à fórmula, objetivos e estilo, e ao mesmo tempo se contrapõe aos espelhos de príncipe tradicionais ao inserir uma nova perspectiva para este gênero textual, que é a de introduzir o realismo político.

O gênero 'espelho de príncipe' parece existir desde o século IV a.C, mas se consolida nos países europeus no século XIII ${ }^{\text {xii. }}$ Os traços centrais deste gênero se referem ao seu receptor declarado - um governante, e muito habitualmente um governante que está prestes a assumir um governo (por exemplo, faziam-se espelhos de príncipe para os primogênitos de monarcas já idosos) - e um conteúdo específico, que é a discussão da arte de governar. Este último aspecto sintoniza-se com o primeiro, realçando aquela que é sem dúvida a 'função' dos espelhos de príncipe: 'ensinar ao governante tudo sobre o bom governo'. O 'estilo' costuma ser sistematizador, tratadista, ou mesmo pedagógico, primando por um caráter argumentativo que se propõe a convencer o futuro governante acerca da melhor forma de se portar no poder e de tratar os seus futuros governados, bem 
como de lidar com os negócios públicos. A construção da imagem de governante adequada, na qual deve se "espelhar" o governante, é evidentemente outro ponto central. O conteúdo dos espelhos de príncipe, desta forma, apoia-se em uma discussão ao mesmo tempo ética e prática. Com relação a este último termo, trata-se de ensinar o futuro governante a governar adequadamente; mas com relação ao primeiro termo (o aspecto ético), é mais do que isso, pois o que se almeja é ensinar ao futuro governante o "bom governo". Os deveres e direitos do governante, sua responsabilidade para com aqueles que irá governar, são aspectos centrais deste discurso. Em vista disto, se o governante (o rei, o príncipe, ou outro equivalente) é um personagem central, outro personagem de igual importância, mas genérico, é o Povo, ou aquela realidade coletiva que deverá ser governada. Aparecem também os personagens específicos: os políticos em diversas funções, os conselheiros, os familiares do governante, os trabalhadores que compõem a máquina administrativa governamental, os aliados e opositores políticos, os representantes dos poderes religiosos com os quais se terá de lidar, os demais governantes. Os inimigos, e a forma de lidar com eles, constituem importante capítulo à parte.

Há questões de fundo que afetam as relações do governante com estes personagens. A quem se aliar? A quem combater? Como tratar o inimigo? Como tratar o vencido? Quando ser piedoso, e quando ser severo? Como se impor ao Povo, e o que se deve fazer no seu interesse? Por fim, há as questões que se voltam para si mesmo: como deve se autoformar o governante? Que imagem deve projetar de si mesmo? Maquiavel, no Capítulo XVII de seu livro, irá perguntar: "é melhor ser amado, ou ser temido"? Com relação aos instrumentos dos quais precisará se valer - as armas, recursos, a constituição - existem aspectos que pautam a reflexão a ser desenvolvida pelos espelhos de príncipe. Qual a Constituição ideal? Por fim, se o tema-base dos espéculos é o "bom governo", uma estratégia discursiva recorrente é contrapor a este o "mau governo". De igual modo, o "bom governante" pode ser espelhado contra o "mau governante", e a forma ideal de governo contra as formas deterioradas.

Aspecto igualmente importante dos espelhos de príncipe se refere àquele que o produz (portanto, ao seu lugar de produção). Supõe-se que o autor, para ousar escrever tal obra de aconselhamento sistemático, seja alguém que teve ampla experiência com o poder, que o conhece em profundidade. Uma vez que os ensinamentos que se encaminham nos espéculos ligam-se a virtudes e valores mais amplos, supõe-se que seu autor seja também um sábio. Para além da autoria individual, também não eram raros espelhos de príncipe escritos por comissões de autores experimentados, como o famoso Livro dos Doze Sábios, manuscrito 
da Castela medieval. O elemento moralista também costuma estar presente nos espelhos de príncipe, que pode ser entendido como uma especulação moral sobre o poder civil.

Podemos, neste momento, retomar o diálogo do Príncipe de Maquiavel com os diversos espelhos de príncipe que o antecederam, e que contribuíram para constituí-lo como gênero. Habitualmente, os espelhos de príncipe parecem preocupados em fixar uma imagem de governante perfeito. Trabalham, portanto, com uma perspectiva idealista. Maquiavel, tal como já vimos, propôs-se a trabalhar com um realismo político. Há uma passagem do Capítulo XV de $O$ Príncipe, aliás, na qual este programa de realismo político é claramente afirmado e explicitado:

\begin{abstract}
Sendo minha intenção escrever algo útil para quem se dispões a entendêlo, pareceu-me mais conveniente perseguir a verdade efetiva do que a sua idealização. Muitos imaginam repúblicas e principados que nunca foram vistos nem conhecidos no mundo real, Mas há uma distância tão grande entre como se vive e como se deveria viver, que aquele que deixa aquilo que se faz por aquilo que se deveria fazer aprende mais o caminho da própria ruína do que o de sua preservação (MAQUIAVEL, 2000, p.116) ${ }^{\text {xiv }}$.
\end{abstract}

Neste quadro político efetivamente real previsto por Maquiavel, o governante não pode ser perfeito - não deve ser visto, por exemplo, como um ser superior indicado por Deus. Deste modo, tanto o governante abordado pelo autor florentino não se coloca como perfeito, assim como, muito menos, precisará ou poderá lidar com uma realidade perfeita, pronta a se ajustar servilmente à imagem idealizada do governante perfeito ${ }^{\mathrm{xv}}$. É em vista disto que podemos dizer que $O$ Príncipe de Maquiavel tanto se funda como uma contribuição significativa e inovadora na já extensa linha de 'espelhos de príncipe', como reinventa a função deste gênero literário e discursivo tradicional. Não se trata mais de mostrar a imagem do governante perfeito a um aprendiz de governante ungido por Deus, mas de sim de instruir um homem até certo ponto comum - este que irá se preparar diligentemente para o objetivo de se tornar e atuar como governante - acerca da realidade política tal como ela se apresenta na sua situação concreta, efetiva, demonstrável a partir dos próprios casos que ocorrem cotidianamente nos ambientes da grande e da pequena política, e também pelos que são trazidos pela história ${ }^{\text {xvi }}$. Este rompimento com o idealismo político dos espelhos de príncipe tradicionais é que refunda o gênero nas mãos de Maquiavel. Não se trata mais nem de considerar um governante ideal como 'objeto de análise', e nem de projetar para fora, como ‘construção ideológica' destinada a impressionar o povo, a imagem de um governante ideal. No exercício de sua atividade política, ainda que 
o governante possa manipular imagens a seu favor, deverá se dar ao direito de agir conforme a necessidade imposta pela realidade.

Há outro aspecto interessante que decorre da contraposição entre $O$ Príncipe de Maquiavel e os espelhos de príncipe que eram típicos da Idade Média. Com alguma frequência, os espelhos de príncipe medievais recorriam a exemplares (exempla) extraídos de passagens bíblicas. O exemplum, como já mencionei em outro momento, é o texto de qualquer tipo - anedótico, fabulista, bíblico, mítico, histórico - que é utilizado como exemplo didático para fixar um modelo de comportamento, e que deste modo cumpre uma função pedagógica voltada, sobretudo, para aspectos éticos. Nos espelhos de príncipe, os exemplos são muito recorrentemente extraídos da Bíblia, assim como suas máximas também são citadas. Isso faz da Bíblia uma das fontes mais importantes - se não a mais importante - dos espelhos de príncipe tradicionais da Idade Média. Maquiavel, em contrapartida, utiliza exemplos históricos - o que sintoniza com a sua perspectiva de que a história é "mestra da vida" (magistra vitae). Além disso, sua preferência é pelos exemplos laicos, ou humanos no sentido da vida corrente.

O humanismo e a inserção em uma sociedade renascentista, desta forma, sintonizam-se com esta redefinição do gênero por Maquiavel. Com essa transição dos exemplos bíblicos típicos dos espéculos medievais para os exemplos históricos e realisticamente humanizados do Príncipe de Maquiavel, este autor rompe com a perspectiva religiosa no tratamento desta matéria. Também há uma ultrapassagem da ética tradicional dos espelhos de príncipe em favor de uma perspectiva mais prática. A religião deixa de apresentar-se como uma perspectiva modelar - um horizonte de inspiração e de perfeição a ser contemplado - e passa a se encarada como um grande personagem que precisa se considerado pelo príncipe. A religião, os conteúdos religiosos, e particularmente os agentes religiosos podem ser bons ou maus (úteis, inúteis e nocivos) para a ação do príncipe. Aprender a lidar com eles é parte de sua formação, da mesma maneira como é necessário a aprender a lidar com a população governada, com os governantes estrangeiros, com as forças políticas de modo mais geral. A religião, em certas passagens, chega mesmo a ser tratada como instância passível de instrumentalização pelo político. Por fim, a intenção declarada de Maquiavel é a de revelar ao príncipe como balancear a astúcia e a força - ou a de mostrar ao governante como alternar, em si mesmo, as figuras da raposa e do leão. Uma coisa sem a outra pode levar o príncipe à ruína; mas com ambas integradas, e evocadas cada qual em seu momento propício, configura-se a possibilidade efetiva de que o conjunto 
de qualidades do príncipe - a Virtu - associe-se à Fortuna para a obtenção dos melhores resultados possíveis na conquista do poder e na condução do governo.

\section{O Príncipe e seus possíveis problemas históricos}

Situemos até aqui um balanço inicial dos aspectos que, como vimos, estão envolvidos no 'lugar de produção' de $O$ Príncipe. No início da era dos impressos, temos esse autor - pertencente a uma certa classe social, inscrito em uma trajetória intelectual específica e possuindo uma visão de mundo humanista-renascentista. Está bem inserido em sua própria época, em uma sociedade bem definida, e em uma região que se acha dividida e interferida por tensões internas e externas. Um conturbado contexto político o introduz em circunstâncias específicas, e é nesse emaranhado de linhas de forças que ele se põe a escrever uma obra que expressa um peculiar diálogo intertextual com o antigo gênero dos ‘espelhos de príncipe'. Propõe-se, de sua parte, a explorar uma nova lógica que já pode ser entendida como um realismo político em formação. Ao decifrar este conjunto de complexidades, a compreensão deste 'lugar de produção' permite-nos tratar a obra como fonte histórica.

Que problemas históricos poderemos investigar a partir desta fonte? O uso de exemplares da antiguidade romana em uma obra política do renascimento humanista do início do século XVI? A história intelectual de seu autor? Um novo encaminhamento que se dá para um antigo gênero literário que havia atingido seu ponto de consolidação nos três séculos anteriores? A emergência do realismo político? Seu contraste com o idealismo político, em seu próprio século, ou nos séculos anteriores? Aspectos locais da própria política florentina? O seu diálogo com as instâncias religiosas, ou a sua inserção em um certo ambiente econômico que coloca em interação grupos sociais diversos? Uma rede de intertextualidades? O uso da concepção da "história mestra da vida" em uma obra voltada para a praticidade política? Poderíamos, talvez, comparar a obra com outras de sua própria época ou de outras épocas? Seria o caso de examinar os personagens específicos que aparecem nesse ambiente político, ou quem sabe a questão do exército de mercenários em uma Europa na qual as grandes monarquias centralizadas já formaram seus exércitos permanentes? Seria o caso de investir em maior profundidade na compreensão acerca da historicidade de certos conceitos, tal como eles se apresentam na obra - o de povo, tirania, república, entre outros tantos? Ou poderíamos avançar para a recepção desta obra de 
Maquiavel em outras épocas, superpondo diferentes lugares de produção ao examinar as leituras que filósofos como Diderot e Rousseau fizeram do Príncipe, ou mesmo os modos como governantes, políticos e homens de ação se apropriaram da obra para pensá-la na sua praticidade, a exemplo de Napoleão Bonaparte ou de Mussolini? Os problemas históricos são inúmeros, mas para todos eles não podemos nos aproximar de uma fonte histórica específica sem compreender muito claramente o seu lugar de produção.

Um problema adicional é o das diferentes leituras ou reapropriações de $O$ Príncipe, ou pelo menos os distintos impactos que foram produzidos por esta obra de Maquiavel em diferentes receptores. Assim que publicado, em 1532, O Príncipe passou a ter uma divulgação maior, típica de um livro bem sucedido da era dos impressos, e daí em diante inicia sua múltipla trajetória de republicações, traduções, reapropriações, releituras e citações ao longo da História das Ideias Políticas, chegando até os dias de hoje tanto como um clássico a ser estudado em diversos campos do saber, como também se afirmando como obra prática e de reflexão realista que tem frequentado a mesa de cabeceira de muitos políticos ou mesmo por empresários que enxergam suas empresas como microambientes políticos.

O Príncipe não escapou do Index - a lista de livros proibidos que a Igreja Católica, ainda no século XVI, iria elaborar durante o Concílio de Trento. Como se sabe, este concílio foi realizado em muitas seções entre 1545 e 1565, legislando e decidindo sobre assuntos pertinentes à administração, política e vida religiosa - debatendo e estabelecendo posições e normas sobre questões que iam da proibição de livros ao tipo de música que deveria ser considerado para a composição de missas. A Reforma Luterana havia sido bem sucedida, e era agora preciso combatê-la com uma Reforma Católica, movimento de reestruturação da Igreja que a historiografia mais antiga costumava denominar Contra-Reforma. O Príncipe de Maquiavel terminou por ser indicado em 1559 como um dos livros proibidos pelo Index ${ }^{\text {vvii. }}$ Isso não impediu que a obra adquirisse grande visibilidade e ultrapassasse os limites de Florença, da Itália, da Europa, e que também fosse projetada para outros séculos, tornando-se parte integrante dos repertórios de textos básicos da Filosofia e da Ciência Política em lugares-tempos os mais diversos.

De um ponto de vista hitoriográfico, é muito interessante refletir sobre as diferentes leituras da obra que foram elaboradas por autores de sociedades e tempos diversos - com distintas posições sociais, dotados de distintas perspectivas capazes de reinserir o texto de Maquiavel em novas redes de intertextualidades, e examinando-a sempre com um olhar específico que se torna possível diante de novos contextos. Reis, 
nobres, burgueses, militares, líderes operários, militantes políticos de esquerda ou de direita, negociantes em sua trajetória de conquista do poder econômico, filósofos e cientistas políticos, entre inúmeros outros produtores de discurso, leram este livro em países diversos da Europa, das Américas, dos demais continentes, produzindo novas leituras desta obra, nela percebendo novos aspectos e reconstruindo outros através de uma leitura criativa. Cada uma destas novas leituras recriadoras de uma obra também tem o seu lugar de produção, o que nos dá mostras de que todo texto, uma vez criado pelo seu autor e posto a circular, adquire uma vida própria aberta a novas reapropriações - novos modos de ler um texto, e novas possibilidades de criticá-lo ou interpretá-lo. Há comentaristas célebre de $O$ Príncipe, que sobre esta obra produzem releituras que muito falam de suas próprias épocas e da concepção dos seus analistas. Entre estes, podemos lembrar os nomes de Jean-Jacques Rousseau (1712-1778), Frederico II e Napoleão Bonaparte. A discussão sobre estas diferentes releituras da obra certamente mereceriam um artigo à parte.

Para a historiografia, devemos sempre considerar que uma fonte histórica só adquire o seu sentido maior, ou mesmo se constitui como corpus documental disponível para a prática historiográfica, quando para ela dirigimos problemas históricos específicos. É essa dialética entre a fonte histórica e o problema histórico aquilo que constitui a base primordial do trabalho historiográfico. Uma fonte textual como $O$ Príncipe pode constituir por si mesma uma base de reflexão para a Filosofia ou para a Ciência Política, mas para a História - enquanto campo de saber - essa fonte textual só começa a dizer alguma coisa efetiva quando é posta a interagir com problemas históricos específicos. Estes, entrementes, são inúmeros. Posso dar alguns exemplos em subáreas da história as mais diversas, da história militar e da história comparada à história das ideias políticas.

A própria possibilidade de posicionar o texto de Maquiavel no seio da história dos projetos de unificação italiana, por exemplo, adquire sentido ao final dos últimos capítulos de O Príncipe, confluindo para aquele capítulo derradeiro no qual o autor florentino praticamente faz uma exortação para que a família dos Médici assuma o projeto de unir os povos da península Itálica frente a uma Europa que já tinha as suas monarquias centralizadas típicas do início da modernidade. Nesta argumentação de encerramento, Maquiavel pretende convencer os novos donos do poder em Florença, em especial a Lorenzo II, de que este possui a Virtu que poderia redirecionar a Fortuna nesta direção. Sabemos que um movimento efetivo de unificação italiana só irá se concretizar no século XIX, assim como também ocorrerá na Alemanha, e que a persistência das cidades e regiões italianas como pequenas repúblicas e principados vinha se apresentando como uma permanência que atravessara a Idade Média 
amparada no sucesso de muitas destas cidades na área comercial. Na modernidade, entretanto, estas cidades-estados já começavam a se mostrar anacrônicas perante um fenômeno novo e uma nova estrutura de poder e governo extremamente eficaz que fora introduzida com as monarquias centralizadoras.

O impulso inicial destas novas estruturas nacionais vinha de Portugal e da Espanha, que impunham suas monarquias centralizadoras desde fins da Idade Média, fortemente motivados pelas lutas da Reconquista contra os mouros que já estavam bem estabelecidos na

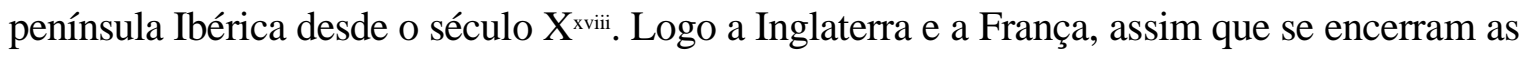
batalhas recíprocas que mais tarde ficaram conhecidas como Guerra dos Cem Anos ${ }^{\text {xix }}$, encontram uma estabilidade análoga, a partir da qual se acham mais à vontade para fortalecer decisivamente as instituições monárquicas centralizadoras, com seus poderosos instrumentos de centralização do fisco, da justiça e da violência física militar - esta última pautada na criação e manutenção dos exércitos regulares nacionais - sem esquecer a concomitante formação de um forte sentimento de identidade nacional na população. É contra esse quadro de formas de governo de um novo tipo, eficazes e centralizadoras, que se confronta uma Itália instável e dividida em muitas repúblicas e principados. O investimento de Maquiavel na exortação a uma unificação itálica, com os últimos capítulos de $O$ Príncipe, corresponde a uma adaptação deste pensador a um novo modelo que vinha se impondo com a modernidade europeia. $\mathrm{O}$ autor florentino é e continua a ser um republicano, tal como bem atestam os Diálogos sobre a primeira década de Tito Lívio - uma obra que ele já começara a escrever antes do Príncipe, mas que só concluirá em 1521, sendo sua publicação adiada ainda para mais além (1531). Não obstante, apesar da perspectiva republicana dentro da qual sempre se posicionou, a realidade histórica parecia mostrar a Maquiavel que o modelo do principado anunciava ser, naquele momento, o mais indicado para instrumentalizar esta unificação, tal como ocorrera nos demais países da Europa continental e também com a Inglaterra. Essa posição de Maquiavel como homem moderno que dá mostras de compreender a modernidade e o que estava nela implicado - sendo a formação dos grandes estados centralizados um destes fatores - explica a sua concessão como republicano à forma de governo principesca. Ele pretende lidar com esta dissonância entre o modelo de governo que considera mais evoluído - a República - e o modelo de governo que o momento da história europeia parece exigir para proporcionar na Itália o desenvolvimento de novas estruturas econômicas e mais fortalecidas de um ponto de vista militar e político: os principados centralizados em torno da figura de um monarca forte que controle as armas (centralização da violência física legítima), as leis (a justiça) e o físco. 
Esse passo também nos permite inscrever o Príncipe em um corpus documental adequado para o estudo de um problema historiográfico ainda mais abrangente do que a unificação política de península Itálica. Não seria um problema historiográfico particularmente pertinente, a ser acessado pela fonte maquievaliana, o da própria formação dos estados modernos - estados que conhecem cada qual um processo centralizador próprio com pelo menos três facetas bem visíveis: o controle crescente do fisco, da justiça e da violência física legítima? Há mais de um século de historiografia, já se encontra bem estudado e teorizado o grande conjunto de processos centralizadores que favoreceu a formação dos estados modernos - e autores como Marc Bloch, Joseph Strayer e Norbert Elias são apenas alguns dos exemplos de pesquisadores que ajudaram, no início deste desenvolvimento historiográfico, a esclarecer os fatores que regeram este processo ${ }^{\mathrm{xx}}$. Na época de Maquiavel, entrementes - mesmo porque os estados modernos estavam ainda em formação e, aos seus contemporâneos, não era tão fácil perceber, em todas as nuances, o fenômeno político que em breve iria se generalizar no mundo moderno - estava ainda longe de ser realizada uma teorização mais completa sobre a tendência centralizadora em curso. Depois viriam muitas teorias, interpretações e pesquisas sistemáticas que dão conta de compreender o que se passava na transição da Idade Média europeia à modernidade. Parece-nos extraordinária, nos dias de hoje, a percepção que Maquiavel conseguiu desenvolver sobre estes processos, expressa em alguns insights de $O$ Príncipe.

Um destes insights situa-se no Capítulo XII de O Príncipe, e também em outras passagens, com o destaque maquievaliano de que "as bases principais de todos os Estados sejam novos, antigos ou mistos - são as boas leis e os bons exércitos". Da tríade de elementos imprescindíveis para a consolidação de um Estado centralizado em torno do monarca - (1) o 'controle da violência física legítima', desautorizando outras forças militares internas de âmbito privado ou senhorial, (2) o 'controle unificado da justiça', confrontando a antiga fragmentação do exercício do poder de julgar nos âmbitos feudais, e (3) a 'unificação do físco' em torno do príncipe - Maquiavel ilumina em sua análise pelo menos os dois primeiros. "Boas leis e boas armas" constituem a sua fórmula essencial para a consolidação de um principado ${ }^{\text {xxi }}$.

De acordo com o autor florentino, estas últimas - as "boas armas" - deviam constituir preferencialmente um exército próprio, permanente, formado por profissionais bem remunerados e beneficiados por um treinamento adequado. Era exatamente isso o que começava a acontecer nas monarquias centralizadoras que já se haviam formado na Europa, e cujo modelo Maquiavel pretendia propor para uma Itália a ser unificada por um príncipe de novo tipo, tal como sugere no último capítulo de seu ensaio político (capítulo XXVI). Temos aqui, portanto, um problema historiográfico particularmente importante para cujo estudo $O$ 
Príncipe pode se integrar como fonte histórica a ser abordada. A perspectiva de Maquiavel sobre a formação dos estados modernos é tanto sintoma de uma nova época, como também não deixa de constituir um agente histórico nesta mesma direção, embora o príncipe da família Médici ao qual ele dedicara a obra não tenha recebido o manual político deste autor florentino com grande atenção ou entusiasmo. Da mesma forma, tal como veremos mais adiante, é muito oportuna a comparação entre a concessão à unificação política conduzida pelo príncipe, que aparece no Príncipe de Maquiavel sob a forma de uma exortação para que a Casa dos Médici se lance a esta empresa unificadora, e o apreço do autor florentino à liberdade republicana que ele via nas poucas repúblicas italianas e também em algumas cidades alemãs de sua época. De todo modo, ainda que saibamos do republicanismo de Maquiavel através de toda a sua vida pregressa e de outras obras que ainda viriam, é incontornável a exortação que o último capítulo de $O$ Príncipe faz à unificação, mesmo que apelando à força principescax ${ }^{x i i}$.

A articulação do pensamento maquievaliano com a percepção de que a Itália estaria pronta para acompanhar o grande movimento de formação dos estados modernos - estes que já vinham se unificando no que concerne ao controle interno da justiça, do fisco e da violência física - leva a que, no capítulo XXIV de seu livro O Príncipe, Maquiavel esteja particularmente preocupado em discorrer sobre "os motivos de os príncipes da Itália terem perdido os seus reinos" (MAQUIAVEL, 2000, p.166). A explicação, a partir deste ponto, direciona-se para uma outra ordem de questões, igualmente importante e digna de ser abordada como mais uma possibilidade de problema historiográfico. O autor florentino explica estes fracassos diversos através da ocorrência indevida de aplicações inadequadas da Virtu (qualidades principescas que podem ser instrumentalizadas) à Fortuna (forma expressa pelas circunstâncias nos vários momentos). É muito interessante relembrar uma das metáforas maiores que Maquiavel evoca para compreender as imposições do destino e a necessidade de enfrentá-las adequadamente:

Comparo a sorte [Fortuna] a um desses rios impetuosos e transbordantes que, quando se enfurecem, alagam as planícies, destroem as árvores e os edifícios, deslocam porções de terra de uma parte para outra. E todos fogem desta fúria desastrosa, todos capitulam diante do seu ímpeto, sem poder de alguma forma se lhe opor. Entretanto, embora tais coisas aconteçam, não se impede de que, em tempos de tranquilidade, os homens tomem providências por meio de proteções e diques, de mo que, quando certos rios depois cresçam em volume de água, na cheia, possam ser canalizados e sua fúria possa deixar de ser desenfreada e danosa (MAQUIAVEL, 2000, p.169170). 
A metáfora do rio pode ser evocada tanto para os acontecimentos mais específicos relacionados a cada príncipe ou ser humano em particular, como pode remeter aos grandes movimentos da História. Um pouco mais adiante, Maquiavel sustenta a ideia de que "experimenta a felicidade do sucesso aquele que combina seu modo de proceder com a natureza dos tempos" (MAQUIAVEL, 2000, p.171). Nos próprios termos maquiavelianos, trata-se de ajustar à Virtu à Fortuna, ao mesmo tempo em que nos empenhamos em dominar a última através da primeira, redirecionando a Fortuna de acordo com nossas próprias metas ou nos deixando por ela levar no momento certo. Sim, esta dinâmica entre a Virtu e a Fortuna pode ser aplicada à experiência individual e à especificidade da aventura pessoal de cada príncipe em particularxxiii. Mas não estaria Maquiavel insinuando que a Itália, como personagem mais amplo no drama da história, precisava adaptar a sua Virtu à Fortuna trazida pelos novos tempos centralizadores? Uma reflexão desta ordem insere o discurso maquiaveliano tanto diante do já discutido problema histórico da moderna centralização estatal, como na discussão sobre os novos tipos de sujeitos políticos que seriam requeridos para o novo mundo que já se anunciara.

Ainda considerando exemplificativamente as passagens em que mobiliza discursivamente a dinâmica entre Virtu e Fortuna, poderíamos considerar agora um problema historiográfico bem distinto. Digamos que fosse nosso interesse investigar o imaginário misógino na Itália renascentista, e $O$ Príncipe de Maquiavel pudesse constituir, entre outras obras, uma fonte histórica para tal problema de investigação. A certo momento de sua argumentação, Maquiavel expande a sua metáfora da interação entre Virtu e Fortuna para a dimensão da dicotomia entre o masculino e o feminino. A Virtu corresponde a um conjunto masculino de atributos - sempre variável, de acordo com cada herói ou com cada ser humano, pois já vimos que Maquiavel rejeita os modelos fixos e idealizados de comportamento que por tanto tempo ressoaram nos tempos medievais dos espelhos de príncipe. A Fortuna, por outro lado, é uma mulher - uma deusa impetuosa mas que sabe ser submetida pelo herói varonil e virtuoso que sabe lidar com a sua natureza volúvel e carente de ser conquistada. Assim resume Maquiavel o enlace amoroso entre o herói dotado de Virtu e a Fortuna:

É melhor ser impetuoso que cauteloso, porque a sorte [a Fortuna] é mulher, e é necessário, caso se queira submetê-la, que seja combatida e contrariada. E se constata que ela mais se deixa dominar por aquele que por este que procede friamente. Essa é a razão de, como mulher, ser a amiga dos jovens, pois estes são menos cautelosos, mais selvagens e comandam com mais audácia (MAQUIAVEL, 2000, p. 173). 
Com este retoque quase irônico Maquiavel finaliza o seu capítulo XXV, intitulado: "De quanto pode a sorte nas coisas humanas e do modo de resistir a isso". Digamos que fosse um problema historiográfico interessante uma investigação sobre as imagens do feminino em O Príncipe, ou na obra mais ampla de Maquiavel, ou mesmo na literatura política da Itália do século XVI - ou, ainda, na literatura dos 'espelhos de príncipe' desde a Idade Média até sua culminância com a modernidade maquiaveliana. Diante destas diversas possibilidades de problemas, este e outros trechos da fonte adquiririam outros significados. Parodiando divertidamente ao próprio Maquiavel - que nos mostra a necessidade principesca de que a Virtu submeta a Fortuna - podemos dizer que, na operação historiográfica, o Problema Histórico deve dominar a Fonte, que a ele resiste mas que, sendo decifrada adequadamente, acaba rendendo-se a ele e ao historiador que o conduz.

A dialética entre Virtu e Fortuna - central no Príncipe de Maquiavel - abre espaços temáticos para muitos outros problemas dignos de serem abordados pelos historiadores. Quentin Skinner (n.1940) - um dos principais historiadores britânicos da conhecida Escola de Cambridge, cujos estudos se direcionam à História das Ideias Políticas - destaca como um dos principais objetos de interesse para os estudos sobre Maquiavel o contraste que pode ser estabelecido entre os tratamentos dados à Virtu pelo autor florentino e pelos autores da Antiguidade Clássica. Para estes últimos, assim como também seria para todos os pensadores políticos subsequentes da Idade Média, a virtude é fixa. Trata-se de um conjunto de qualidades que pode apresentar pequenas variações de autor a autor, mas que sempre é dado como um conjunto fixo de elementos, que transcendem os homens na sua experiência prática. Para os clássicos, as quatro virtudes cardeais seriam a sabedoria, a coragem, a temperança e a justiça. O que Maquiavel introduz com o Príncipe é precisamente a ideia de que a Virtu - em se tratando de príncipes de agem para conquistar e manter o poder - não pode se configurar de modo algum em um conjunto rígido de qualidades morais. A Virtu é um conjunto de qualidades flexíveis de que o príncipe dispõe - e cada príncipe em particular tem seu próprio repertório de características - de modo a se combinar com a Fortuna que a ele se apresenta. Desta combinação - que pede flexibilidade e não rigidez, que demanda uma ética de resultados e não uma moral estabelecida de vez por todas a partir de um mundo supralunar -é que advém o sucesso político.

Deste modo, apresenta-se como problema historiográfico comparar o pensamento de Maquiavel sobre a Virtu e o pensamento predominante nos séculos anteriores. Diante da formação dos novos estados centralizados e de outros fatores que introduzem a modernidade, porque se torna possível introduzir esta nova postura diante dos modos de agir? Que condições 
históricas amparam a possibilidade de pensar de uma nova maneira, de propor uma tábua flexível de valores? No entanto, o humanista Maquiavel continua a dialogar com os clássicos, e todas as noites veste os seus trajes especiais para ir ter com eles em seu escritório silencioso, mas habitado pelas vozes do passado. Este confronto dialético faz de Maquiavel um homem de sua própria época, que bem compreende o que está em jogo com o advento dos tempos modernos, mas que retoma os pensadores da Antiguidade clássica, saltando esse período medieval que muitos dos intelectuais humanistas consideraram como "uma longa noite de mil anos”. Este diálogo entre os mundos moderno e clássico - do qual Maquiavel é apenas um dos seus muitos representantes e interlocutores renascentistas - é um dos problemas historiográficos de grande interesse que podem se beneficiar do uso do Príncipe como fonte histórica.

Vejamos agora outros problemas possíveis a partir de $O$ Príncipe. Pode-se dar que a investigação historiográfica se estabeleça em torno da temática da evolução e desenvolvimento dos manuais de política, partindo dos modelos idealizadores da Idade Média propostos pelos ‘espelhos de príncipe' até chegar à sua inflexão realista com $O$ Príncipe de Maquiavel. Não seria interessante uma investigação historiográfica que se ativesse ao problema da separação entre a ação moral e a ação política, do qual a reflexão que se desenvolve na passagem para os tempos modernos toma consciência maior precisamente com $O$ Príncipe de Maquiavel? Há toda uma comparação intercontextual entre a Idade Média e a modernidade que pode ser beneficiada por este aspecto tão presente nas páginas de $O$ Príncipe. Qual era o papel de instituições medievais como a Igreja no entrelaçamento entre estas duas matrizes de ação - a Moral e a Política - e por que motivos a modernidade do Príncipe abre tão claro espaço de reflexão para a distinção entre uma coisa e outra, apesar do eterno contraponto que, a partir daí, continuaria a confrontar estas duas maneiras de ver o problema até chegar a leitores posteriores que representam uma e outra destas correntes, como Frederico II e Napoleão Bonaparte?

Neste último patamar, e com relação ao Príncipe de Maquiavel e sua ampla variedade de ideias tanto concernentes ao mundo da política como aos aspectos éticos, deve o historiador se mostrar mais francamente interessado nas respostas que a obra maquiaveliana dá aos problemas específicos de seu tempo, ou nas respostas que os seres humanos de outros tempos através dela conseguiram escutar, em outros contextos históricos e sociais? Não será particularmente interessante uma História Comparada que se disponha a analisar, no interior de seus contextos históricos mais específicos, estas leituras tão diversas sobre $O$ Príncipe que foram elaboradas pela Rainha Cristina da Suécia (1626-1689), pelo rei prussiano Frederico II 
(1712-1786), pelo ditador fascista Benito Mussolini (1883-1945), pelo filósofo marxista Antônio Gramsci (1891-1937), ou pelo general-imperador Napoleão Bonaparte (1769-1821)? Neste último caso, não deveria haver um importante interesse historiográfico em verificar a veracidade (ou falsificabilidade) dos comentários publicados em nome de Napoleão sobre $O$ Príncipe, nos quatro contextos que o conduzem do generalato ao exílio na Ilha de Elba? Ou, ao contrário, não se trataria de submeter à investigação as infiltrações que eventualmente podem ter ocorrido nestes comentários, e a que interesses e demandas sociais ou editoriais elas atenderiam? ${ }^{\text {xiv }}$

Os estudos sobre a recepção de $O$ Príncipe não se limitam às leituras que foram feitas sobre Maquiavel em épocas posteriores, pois já na própria época do autor florentino - por exemplo, na própria Itália renascentista - já podemos assistir à instalação de uma polêmica que termina por gerar novas obras, de outros autores, às vezes dedicadas à refutação ponto a ponto do ensaio político de Maquiavel - tal como faria Agostinho Nifo em um texto de $1521^{\mathrm{xxv}}$ - e às vezes inserindo Maquiavel em discussões mais amplas sobre as formas de governo ou outros temas que foram abordados pelo autor florentino. Antonio Brusciolli, por exemplo, escreve em 1526 um diálogo chamado Della Repubblica, no qual insere Maquiavel como um dos personagens-interlocutores; algo similar é feito por Luigi Guicciardini, que também apresenta o autor de $O$ Príncipe como interlocutor em um diálogo datado de 1530. A partir destes e de outros exemplos podemos ver que há um impacto importante do pensamento maquiaveliano (e da sua distorção "maquiavélica”) já na sua própria época, o que, inclusive, logo levaria $O$ Príncipe de Maquiavel à inserção no Index dos livros proibidos pela Igreja Católica do Concílio de Trento, algumas décadas mais tarde (1559) xxvi. Um patamar de problemas historiográficos importantes, portanto, refere-se à possibilidade de tomar como fonte $O$ Príncipe, e outras obras de outros autores que com ele polemizaram, de modo a encetar um estudo sobre a recepção de Maquiavel na sua própria época, e com vistas a, principalmente, indagar sobre porque as ideias evocadas em seu manual político tiveram tanta repercussão e potencial de perturbação no campo da reflexão política. Os tempos modernos haviam chegado, poderíamos acrescentar, e a polêmica que se estabelece em torno obra de Maquiavel é um dos seus sintomas.

Além de um autor poder ser confrontado com outros, pode ser igualmente oportuno confrontar um autor consigo mesmo. As circunstâncias podem ter um papel importante nas inflexões da história intelectual de um autor, e, além disso, um autor não é necessariamente igual a si mesmo em todos os momentos. Como problema historiográfico importante, poderíamos comparar o Maquiavel republicano dos Discursos sobre a Primeira Década de 
Tito Lívio (1513-1521), e o Maquiavel que parece dar aporte aos poderes principescos em $O$ Príncipe (1513). É particularmente fascinante o enigma provocado pela presença do singular livro O Príncipe - com sua dedicatória laudatória e seu sistemático discurso sobre o principado - na rede maior de obras escritas pelo republicano Nicolau Maquiavel. Teria o autor florentino escrito esta genial obra apenas como um astucioso meio de voltar a ter uma perspectiva profissional e política no novo governo florentino que havia sido introduzido pela Casa dos Médici? Ou seja, O Príncipe seria nesse caso apenas a obra de um Maquiavel oportunista, ou ao menos de um homem localmente preocupado com o seu destino pessoal imediato? Em termos maquievalianos, seria essa obra que parece se afastar momentaneamente do republicanismo - quando iluminada pelo conjunto maior das demais obras do autor florentino - apenas uma astúcia da Raposa que habitava a alma do ex-chanceler de Florença?

Se é possível pensar essa hipótese, não há de fato muito como comprová-la, ou mesmo avançar mais na sua demonstração - o que só ocorreria se encontrássemos diários de Maquiavel nos quais ele afirmasse, numa escrita de si para si mesmo, que de fato escrevera o seu manual político com objetivos de se mostrar ao novo governante como um hábil e experiente político que ele bem faria em indicar para algum cargo, talvez a velha Chancelaria que ele ocupara durante o governo republicano de Soderini. Não temos esse diário como fonte histórica disponível - pois, se existiu um dia, não sobreviveu à seleção do tempo com relação aos documentos que são guardados de modo a se tornarem "passados-presentes". Também não encontramos essa confissão de Maquiavel em correspondências a amigos. Se, em 1513, ele fala a seu amigo Francesco Vetttori sobre seu novo livro (O Príncipe), nada mencionou sobre esta motivação mais maquiavélica do que maquievaliana. De todo modo, se o que Maquiavel queria mesmo, segundo esta hipótese, era tão somente cair nas boas graças do novo governante ou angariar dele algum cargo político ou diplomático - ou ao menos obter uma singela autorização de retornar a Florença - isso não ocorreu de fato. Lorenzo II não deu nenhuma atenção à sua obra ou a seu autor, e Maquiavel continuou a ser ostracizado das funções públicas. Por outro lado, quando este governante falece inesperadamente em 1519, e o governo de Florença passa a ser controlado pelo cardeal Júlio de Médici, somente então este último resolve oferecer a Maquiavel o cargo de historiador da república florentina. De qualquer maneira, o plano imediato de conquistar favores de Lorenzo II, se algum dia existiu, não surtiu efeito.

Continuemos com as hipóteses que se referem ao contraste entre $O$ Príncipe e os Diálogos sobre a primeira década de Tito Lívio. Teria a obra O Príncipe, conforme diriam mais tarde Rousseau e Diderot, um verdadeiro destinatário oculto que não era o príncipe 
Lorenzo II? Seria esse destinatário oculto o próprio Povo, ou os seres humanos comuns que compõem a multidão dos governados? Será que eram eles a quem Maquiavel realmente almejava de maneira dissimulada, sob as laudatórias palavras da dedicatória que fizera a Lorenzo de Médici? Lembremos esta conjectura: ao pretensamente ensinar aos príncipes o que eles já sabem, Maquiavel estaria na verdade ensinando ao Povo e aos cidadãos comuns algo sobre os príncipes, dotando-lhes de um saber que poderia ajudar a preveni-los contra os políticos e governantes.

Tampouco há muito a dizer sobre a possibilidade de comprovar esta hipótese a partir de registros em outros tipos de fontes, e apenas podemos demonstrar uma hipótese como essa propondo uma certa leitura de $O$ Príncipe - pois este livro, de fato, se pode ser lido a partir da perspectiva dos príncipes, também pode ser lido a partir da perspectiva do povo. Além disso, temos um indício algo curioso, pois, em certa passagem dos Discursos sobre a primeira década de Tito Lívio, Maquiavel critica "aqueles que dedicam obras aos príncipes" (!) Não obstante, alguém poderia argumentar que isto poderia representar apenas uma correção honesta do Maquiavel republicano em relação ao pequeno desvio oportunista pelo qual o autor maquiavélico enveredara com a dedicatória a Lorenzo de Médici - a qual, diga-se de passagem, foi uma dedicatória em separado, enviada como carta a Lorenzo de Médici, embora nas edições de hoje esta carta-dedicatória seja quase sempre incorporada como uma espécie de prédica inicial ao texto de $O$ Príncipe.

Há, contudo, um outro indício, no mínimo interessante. Em 1527, a fortuna - deusa da sorte, do azar e dos destinos imprevisíveis, segundo a antiga mitologia romana - parece transbordar "como um rio impetuoso" em uma nova direção. Uma reviravolta na península Itálica terminou por contribuir para que se fizesse eclodir uma revolta republicana que finalmente destituiu o representante dos Médici no governo de Florença. Foi o primeiro abalo nesta longa linha de governo através do qual Florença havia deslizado da república autêntica de 1513 para o governo autoritário sob a égide principesca da Casa dos Médici. Agora, com essa nova reviravolta da roda da fortuna, Florença voltava a ser uma república. Nesta época, Maquiavel já vinha ocupando a confortável função pública de Historiador da República de Florença, à qual chegara por indicação de Júlio de Médici, que havia se tornado o papa Clemente VII ${ }^{x x v i .}$. Ato contínuo à vitória dos revoltosos de 1527, o republicano Maquiavel foi acusado de traidor da república, visto que tanto havia sido beneficiado por uma função pública pelos Médici, como já fora publicado e se tornara bem conhecido o livro que a um deles dedicara, e que até tinha no último capítulo uma exortação para que a Casa dos Médici unificasse a Itália. Contra a acusação de ter escrito um livro anti-republicano, Maquiavel teria 
retrucado que, se havia ensinado aos príncipes de que modo se estabelece a tirania, ao mesmo tempo teria mostrado ao povo os meios para dela se defender (EIDE, 1986, p.49). Teria sido esta fala de Maquiavel, no último ano de sua vida, o que inspirou Rousseau a evocar a hipótese de que verdadeiro objetivo de $O$ Príncipe não era o de ensinar aos príncipes, mas sim ao Povo? Daqui, também Denis Diderot parece tirar uma conclusão bastante similar, claramente expressa no verbete "Maquiavelismo", da Enciclopédia:

Quando Maquiavel escreveu o seu Tratado do Príncipe, é como se ele tivesse dito aos seus concidadãos: «leiam bem esta obra. Se alguma vez aceitarem um senhor, ele será como eu o descrevo - eis a besta feroz à qual vos entregareis». Assim, se seus contemporâneos ignoraram seu objetivo, a culpa é deles. Viram a sátira como um elogio. Bacon, o chanceler, não se enganou quando disse: «este homem não ensina nada aos tiranos, eles sabem muito bem o que devem fazer. Mas ele instrui os povos sobre o que devem temer (DIDEROT, 2015, p.232) xxviii. $^{\text {. }}$

Por outro lado, o indício também não prova nada de forma decisiva, pois Maquiavel estava então nas barras de um tribunal e precisava se defender. Mesmo considerando que ele tenha se desviado dos princípios republicanos com O Príncipe (e ainda que voltando a eles nos Diálogos e nas demais obras), faz alguma lógica que dissesse isto em sua própria defesa. A sua Raposa não deixaria passar isso, deixaria? De um modo ou de outro, o republicanismo de Maquiavel pode ser ainda mais bem demonstrado, acima de tudo, com o próprio texto dos Diálogos sobre a primeira década de Tito Lívio (1513-1521). Comparar esta obra e $O$ Príncipe, e iluminar ambas no interior da trajetória autoral de Maquiavel, é um problema historiográfico particularmente interessante, que não apenas pode ser trabalhado sob o prisma da História Intelectual, como também pode ajudar a compreender o mundo político deste célebre autor florentino ou o contexto da primeira modernidade europeia.

Ao lado das reflexões que surgem de uma comparação entre as duas obras maiores de Maquiavel, podemos também examinar comparativamente a recepção de ambas. Seria possível perseguir a demonstração de uma hipótese sobre porque a primeira (Discursos) foi eclipsada, ao menos no nível de assimilação popular, por esta segunda obra (O Príncipe), ainda que esta seja menos pretensiosa e que, no entanto, tenha se mostrado tão irresistível para as sucessivas gerações de leitores que adentram a modernidade e o período contemporâneo? ${ }^{\text {xix }}$ Entre as investigações de História Intelectual sobre os textos maquievalianos, poderíamos ainda comparar, sistematicamente, as imagens e ideias pertinentes à guerra presentes em $O$ Príncipe e em A Arte da Guerra (1520). Ou, quem sabe, já no âmbito da História Comparada, 
poderia ser elaborada uma comparação entre este último livro de Maquiavel e a Arte da Guerra de Sun Tzu, estrategista chinês do sexto século anterior à Era Comum.

Comparações do Príncipe de Maquiavel em relação a obras de outros autores, no que tange a questões mais específicas, podem constituir um caminho historiográfico interessante para iluminar reciprocamente, um à contraluz do outro, contextos sociais e políticos distintos. Neste caso, a obra torna-se fonte para uma História Política Comparada. Ou, então, pode-se, através destas comparações, prosseguir em uma combinação entre História Comparada e História Intelectual. Uma História Intelectual Comparada poderia examinar, por exemplo, a questão do otimismo ou pessimismo em relação à natureza humana. Por um lado, pode-se verificar como a questão atravessa distintas obras do próprio Maquiavel, como O Príncipe e os Discursos sobre a Primeira Década de Tito Lívio ${ }^{\mathrm{xxx}}$. Por outro lado, pode-se analisar comparativamente a perspectiva pessimista de Maquiavel em contraposição à perspectiva otimista de autores como Rousseau - sendo este último uma escolha interessante porque, ainda que mais fugidiamente, produziu ele mesmo a sua própria leitura sobre $O$ Príncipe, situandoa como uma obra contra os governantes e a favor do povo, que seria o merecedor de seus esclarecimentos enviesados. Em contrapartida, os pessimismos relacionados à natureza humana de Maquiavel e outros autores, como Thomas Hobbes (1588-1679), também podem ser situados em escala comparativa, revelando a incidência nestes autores de novos contextos e redes de intertextualidades.

As possibilidades de pensar problemas históricos que poderiam ser explorados através de $O$ Príncipe, tomado como fonte, são de fato inúmeras. A História do Imaginário e a História das Ideias Políticas também podem se combinar para o estudo de alguns destes problemas. Do filósofo maquievaliano ao político maquiavélico, poderia ser o caso de examinar as várias imagens que se colaram à construção da figura Nicolau Maquiavel, e lançar indagações sobre o que teria proporcionado a projeção de uma sobre a outra. A História Militar, por outro lado, pode encontrar no Príncipe uma fonte capaz de expor informações diversificadas, pois diversos dos capítulos do livro se referem a operações militares, aos diferentes tipos de exércitos (capítulos XII a XIV), e a exemplos que remontam a uma diversidade de eventos bélicos. Os problemas decorrentes de uma Itália ainda muito dependente de exércitos mercenários, e sujeita às reviravoltas e instabilidades por eles proporcionadas, ajudam a compreender como a constituição de 'exércitos permanentes' sob comando político centralizado e ligado à estrutura estatal - deixando para traz o antigo agregado de exércitos feudais que se juntavam ao rei nas ocasiões necessárias - tornou-se um fator importante para a constituição dos estados modernos. Dito de outra maneira, os novos 
estados centralizados da Europa, da Espanha à França, entre outros, iluminam-se à contraluz do caso italiano.

O Príncipe de Maquiavel, enfim, oferece-se como fonte importante para muitos tipos de problemas historiográficos, e estes foram apenas alguns exemplos entre tantos outros que poderiam ser evocados. O primeiro passo para a investigação de qualquer um deles é compreender o lugar de produção desta obra, bem como as chaves de leitura de seu texto e as intertextualidades que as iluminam, sem falar nas demandas sociais que possibilitaram a constituição da obra e nos demais aspectos que podem emergir na análise de profundidade sobre o seu autor. Não obstante, depois deste passo inicial que é a delimitação do 'lugar de produção' da fonte, é preciso investir efetivamente no problema que pode dar sentido a esta fonte, que possa possibilitar a leitura em uma certa direção historiográfica, e não em outra. A construção sistematizada de um encontro entre um problema histórico e um universo de fontes, como se sabe, é a base de qualquer bom trabalho historiográfico.

\section{BIBLIOGRAFIA}

ANGLO, Sydney. (2005). Machiavelli: the first century: studies in enthusiasm, hostility and irrelevance. Oxford: Oxford University Press.

ASPREY, Robert B. (1986). Frederick the Great: The Magnificent Enigma. New York: History Book Club.

BARON, Hans. (1961). Machiavelli: The Republican Citizen and the Author of 'the Prince'. The English Historical Review, vol. 76, n 299, p.217-253.

BIGNOTTO, Newton. (1991). Maquiavel Republicano. São Paulo: Loyola.

BLOCH, Marc. (1982). A Sociedade Feudal. Lisboa: Edições 70 [original: 1939].

BONAPARTE, Napoleão e MAQUIAVEL, Nicolau. (2000). O Príncipe - comentários de Napoleão Bonaparte. Curitiba: Hemus [originais das notas de Napoleão: 1796, 1802, 1804 e 1814].

BRUCIOLI, Antonio. (1526). Dialogi de Antonio Brucioli. Veneza: Gregorio di Gregori. CERTEAU, Michel De. (2011). “A Operação Historiográfica” In A Escrita da História. Rio de Janeiro: Forense Universitária. p.45-111 [original: 1974]. 
COLLARES, M. A. (2010). Visões historiográficas sobre a obra de Tito Lívio. São Paulo: Editora UNESP.

DIDEROT, Denis. (2015). "Maquiavelismo" In: Enciclopédia - ou dicionário razoado das ciências, das artes e dos ofícios, vol.4 - Política.Tomo n 9, São Paulo: Editora UNESP, p.230-232. [original: 1751].

DIDEROT, Denis, (2006). Verbetes Políticos da Enciclopédia. São Paulo: Discurso Editorial / UNESP [originais: 1751-1772].

ELIAS, Norbert. (1990). O Processo Civilizador. Rio de Janeiro: Jorge Zahar Editor [original: 1939].

FERNÁNDEZ ALBADALEJO, Pablo. (1984). La transición política y la instauración del absolutismo. Zona Abierta, $\mathrm{n}^{\circ}$ 30, p. 63-75.

FIRPO, Luigi. (1970), Le origini dell'anti-machiavellismo. Il Pensiero Politico, vol.2, $\mathrm{n}^{\circ} 3, \mathrm{p} .337-367$.

FREDERIC II. (2012). L'Anti-Machiavel: ou Essai de critique sur le Prince de Machiavel [avec toute les corrections de Voltaire]. Paris: Hachette [original: 1741].

GRAMSCI, Antonio (1988). Maquiavel, a Politica e o Estado Moderno. Rio de Janeiro: Civilização Brasileira [original: 1949].

GUICCIARDINI, Francesco. (1983). Opere. Turim: Einaudi [original: 1528].

HESPANHA, António M. (1994). Às vésperas do Leviathan. Instituições e poder político. Portugal, séc. XVII. Coimbra: Almedina [original: 1989].

MAQUIAVEL, Nicolau. (2007-a). História de Florença. São Paulo: Martins Fontes [original: 1520-1525].

MAQUIAVEL, Nicolau. (2007-b). O Príncipe - comentários de Napoleão Bonaparte e Cristina da Suécia. São Paulo: Jardim dos Livros [original: 1513].

MAQUIAVEL, Nicolau. (2000). O Príncipe - comentários de Napoleão Bonaparte. Curitiba: Hemus [original: 1513; 1816].

MAQUIAVEL, Nicolau. (1989). O Príncipe: e dez cartas. Brasília: Editora Universidade de Brasília [original: 1513]. 
MAQUIAVEL, Nicolau. (1987). A Arte da Guerra (e outros ensaios). Brasília: Editora UNB [original: 1519-1520].

MAQUIAVEL, Nicolau. (1982). Discursos sobre a primeira década de Tito Lívio. Brasília: Ed. UNB [original: 1513-1521].

MUSSOLINI, Benito. (1934). "Preludio al Maquiavelli” In: Scriti I discorsi di Benito Mussolini. Milano: Ulrico Hoepli [original: 1924].

PROCACCI, Giuliano. (1965). Studi sulla fortuna del Machiavelli. Roma, Istituto Teorico Italiano.

ROUSSEAU, Jean-Jacques. (1999). Discurso sobre a origem e os fundamentos da desigualdade entre os homens. São Paulo: Nova Cultural [original: 1754].

ROUSSEAU, Jean-Jacques. (1988). O Contrato Social e outros escritos. São Paulo: Cultrix [original: 1762].

SKINNER, Quentin. (1988). Maquiavel. São Paulo: Editora Brasiliense [original: 1981].

STRAYER, Joseph R. (1986). As Origens Medievais do Estado Moderno. Lisboa: Gradiva, s/d [original: 1961].

SUN TZU. (2012). A Arte da Guerra. São Paulo: Martins Fontes [sec.VI a.C].

TITO LÍVIO. (2008). História de Roma - Desde a fundação da Cidade. Belo Horizonte: Crisálida [original: 27-25 a.C].

Submetido em: 18/10/2019

Aprovado em: 22/06/2020

Publicado: 23/09/2020

\footnotetext{
${ }^{\text {i }}$ Professor Associado da Universidade Federal Rural do Rio de Janeiro (UFRRJ).

ii Apesar da publicação só ter ocorrido efetivamente em 1532, o momento aproximado de conclusão da obra é bem conhecido em decorrência de uma troca de correspondências na qual Maquiavel a menciona. Trata-se uma carta de 10 de dezembro de 1513 a Salvador Vettore - um amigo que ocupava o cargo de Embaixador de Florença na República de Roma (MAQUIAVEL, 1989, p.93). Nesta missiva, Maquiavel informa que "acabara de escrever um opúsculo intitulado De Principatibus", ao mesmo tempo em que fala das circunstâncias de produção da obra em sua propriedade em São Casciano.

iii Esparta oferecia o modelo oligárquico propriamente dito. As grandes questões políticas eram decididas pela Gerúsia - um conselho formado por 28 homens de faixa etária superior aos 60 anos - e havia dois reis que compunham a Diarquia, cumprindo funções militares e religiosas. Atenas, depois das experiências monárquica e aristocrática, criou um modelo de democracia, mas da qual efetivamente, ao menos em certo momento,
} 
apenas participava 20\% da população da população (masculina, livre, proprietária). A Roma dos tribunos da Plebe era considerada por Maquiavel um modelo histórico para uma democracia mais ampla.

${ }^{\text {iv }}$ carta de 10 de dezembro de 1513.

v Durante a Baixa Idade Média, verificou-se um notável desenvolvimento da economia mercantil italiana em interação com o mundo feudal circundante. Quando esse mundo começa a se desestruturar, as cidades italianas entram concomitantemente em um processo de perda de controle sobre o comércio europeu.

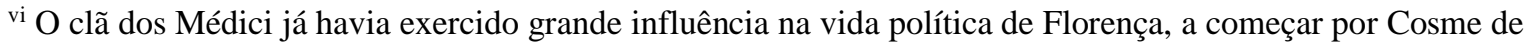
Médici, comerciante e banqueiro que exerceu o poder efetivo na cidade desde 1434, e que o repassa a seu filho Lorenzo de Médici, o magnífico, em 1469. Em 1492, com seu falecimento, o controle do poder passa a seu filho - Piero de Médici - mas este seria expulso da cidade em 1494 por uma conspiração popular liderada pelo monge dominicano Savonarola. A partir daí, os Médici ficaam fora do poder florentino, embora lutando por este em várias ocasiões, até que retornam em 1512 com a deposição de Soderini, que estava no cargo máximo desde 1502. Em 1513, Lorenzo I torna-se o governante de Florença, após seu tio Juliano ter tomado o poder da cidade.

vii A frágil condição das várias repúblicas e principados da península Itálica no quadro das disputas entre as grandes potências europeias, já centralizadas monarquicamente, não apenas é um dos fatores que constituem o lugar de produção de $O$ Príncipe, como também se torna objeto discursivo de alguns de seus capítulos. Particularmente o antepenúltimo capítulo da obra - "Das razões de os príncipes da Itália perderem os seus reinos" (XXIII) - traz alguns exemplos que mostram enviesadamente esta intrincada dialética entre a política interna da península itálica e o confronto entre as grandes potências europeias (França, Espanha, Alemanha, Inglaterra). Por outro lado, o último capítulo de $O$ Príncipe (XXVI), termina por configurar uma exortação pela unificação italiana. Percebe-se aqui o golpe de mestre de Maquiavel, que encerra o livro incitando a própria família Médici à possibilidade de assumir um papel na unificação italiana (MAQUIAVEL, 2000, p.174).

viii As guildas maiores, por ordem de prestígio, eram a dos advogados, a três guildas de mercadores (respectivamente de lá, seda e tecidos), a guilda dos banqueiros; uma grande guilda que abarcava os médicos, boticários, comerciantes de medicamentos, comerciantes de tinturas e lojistas; e, por fim, a guilda dos comerciantes e artesãos que lidavam com peles de animais. $\mathrm{O}$ realce nestas sete guildas permite aos historiadores uma percepção mais precisa sobre quais eram as atividades mais valorizadas na Florença do final da Idade Média e do início do período moderno.

ix A análise de Maquiavel como republicano foi bem conduzida por Bignotto (1991).

${ }^{x}$ Com o governo de Piero Soderini (1450-1520), Nicolau Maquiavel havia ocupado o cargo de Segundo Chanceler da República, que tinha por função a pasta da guerra e da diplomacia.

${ }^{x i}$ É interessante notar que, no momento exato em que concluiu a redação de sua obra, o príncipe-destinatário a quem Maquiavel havia dedicado a sua obra era Juliano de Médici, que acabara de destituir o governante anterior. Juliano, entretanto, ficou muito pouco tempo no poder, e logo o passou a Giovanni de Médici, que finalmente repassou o poder a Lourenço II de Médici. Tudo ficou, naturalmente, em família. Não obstante, Maquiavel precisou mudar a dedicatória antes prevista. Em 1515 ele encaminharia a obra a Lorenzo de Médici com uma carta de apresentação, que nas edições de hoje costuma ser incorporada como uma introdução ao texto. Esta oscilação entre os dois indicados na dedicatória mostra que Maquiavel estava na verdade interessado em dedicar sua obra a um príncipe (um governante), mas não importava muito, no fim das contas, qual dos membros da família Médici seria esse governante, ao fim do processo. Esse detalhe pode ser percebido diretamente na carta de Maquiavel a Francisco Vettore, na qual o primeiro dá notícias ao segundo sobre o seu mais recente escrito (MAQUIAVEL, 2000, p.182).

xii Acredita-se que a peça tenha sido escrita em 1514 - portanto, em uma época bem próxima à elaboração do ensaio político $O$ Príncipe (1513).

xiii Uma das referências mais antigas é o discurso A Nicocles, elaborado por Isócrates em 368 a.C. Igualmente marcantes, já do período medieval, são o Policraticus, de João de Salisbury (1159), o Regimine Principum, de Tomás de Aquino (1266) e o Regimine Principum de Edígio Romano (1287). 
${ }^{\text {xiv }} \mathrm{O}$ Capítulo XV de $O$ Príncipe, embora não haja no livro a indicação explícita de uma divisão que inaugure uma segunda parte da obra, é aquele em que Maquiavel deixa de falar nos aspectos mais propriamente militares da conquista do poder e começa a falar nos aspectos mais especificamente políticos da condução do poder em uma realidade efetiva, habitada por seres humanos comuns, entre estes o próprio governante. É aqui que encontramos a sua explicitação mais formal da perspectiva de realismo político que pretende adotar em seus esclarecimentos.

xv "Pois é inevitável que um homem que queira sempre agir como boa pessoa em meio a tantos que não o são acabe por se arruinar, de maneira que é necessário a um príncipe (que pretenda se conservar no poder) aprender a capacidade de não ser bom e empregá-la ou não segundo a necessidade” (MAQUIAVEL, 2000, p.116-117).

xvi Diz Maquiavel, no último capítulo de sua obra: "E, embora aqueles homens fossem extraordinários e maravilhosos, não deixaram de ser homens" (2000, p.175).

${ }^{\text {xvii } H a ́ ~ p a s s a g e n s ~ d e ~} O$ Príncipe que se opõem à Igreja. Diz um trecho ao final do Capítulo III: “Ao dizer-me o cardeal de Ruão que os italianos não entendiam de guerra, retruquei-lhe que os franceses não entendiam de política, porque, se entendessem, não teriam deixado a Igreja atingir tal proporção" (MAQUIAVEL, 2000, p.59). Além disso, os papas foram tratados por Maquiavel como políticos como todos os outros, a exemplo de Júlio II, um papa que participou diretamente de suas campanhas militares. Tal desmistificação nua e crua dos pontífices não interessava à Igreja já ameaçada pela dissidência da Reforma. Por outro lado, há indícios de que, na Inglaterra de Henrique VIII, os reformistas anglicanos tenham se valido de $O$ Príncipe, desde 1530, na argumentação contra a Igreja Católica (cfe. ANGLO, 2005, p.97-102). Além do que foi dito, é oportuno lembrar que a primeira edição do livro, em 1532, havia sido feita com o aval do papa Clemente VII.

xviii Os dois reinos - Portugal e Espanha - formaram-se e conformaram-se basicamente através da expansão territorial recuperada dos mouros nas lutas da Reconquista. Ambos, neste mesmo movimento, precisaram recorrer à mobilização centralizada de poderes em torno de seus monarcas, antecipando processos de centralização política que somente mais tarde, já no alvorecer da Idade Moderna, surgiriam como demandas incontornáveis para outros reinos europeus.

xix Abrangendo nominalmente uma série de conflitos travados de 1337 a 1453 entre a Dinastia Plantageneta, que governava a Inglaterra, e a dinastia francesa de Valois, a Guerra dos Cem Anos tanto interferiu na estabilidade dos reinos da França e Inglaterra neste período - retardando o seu processo de centralização em comparação aos reinos ibéricos já estabilizados após a Reconquista - como permitiu que houvesse um acúmulo de poder militar em torno dos monarcas, o qual não tardaria a ser utilizado para a consolidação dos estados nacionais francês e inglês. Com isso, França e Inglaterra juntar-se-iam ao quadro dos estados modernos centralizados, na mesma época em que a península Itálica se apresentava como um cenário de fragmentação política e de instabilidade.

xx Marc Bloch desenvolve, em A Sociedade Feudal (1939), uma análise sobre a gradual superação da descentralização feudal em direção às monarquias centralizadas. De sua parte, Joseph Strayer atribui um título significativo ao seu estudo sobre o fenômeno: A Origem Medieval dos Estados Modernos (1961). Norbert Elias retoma a já bem desenvolvida discussão historiográfica sobre os processos centralizadores nas monarquias europeias do fim da Idade Média (Luchaire, 1909), e demonstra como, junto a este processo político, ocorreu concomitantemente um grande processo cultural, que ele denominou Processo Civilizador (1939). Para ambos, os três monopólios - fisco, justiça e violência física legítima - são fatores fundamentais para a formação dos modernos estados centralizadores. Por outro lado, a relativização deste modelo, corrigindo aspectos teleológicos destes sistemas explicativos e introduzindo novas complexidades, viria nos anos 1980 com autores como Fernández Albadalejo (1984) e António Hespanha (1994 e 2001). Este último, ao estudar o Portugal do Antigo Regime, matiza o centralismo estatal com o reconhecimento de um caráter corporativo da monarquia portuguesa (HESPANHA, 2001, 166-167).

xxi Justiça unificada, tributação centralizada e tendência ao monopólio estatal da violência são, desde os últimos tempos feudais, questões perfeitamente interligadas. Uma fomenta a outra - com os recursos obtidos pelo monopólio fiscal contribuindo para reforçar o poder militar do Estado e, inversamente, o poder militar e a sua necessidade atuando no sentido de impor uma tributação crescente. Nada pode impedir, ademais, que os recursos militares voltados para a segurança externa ou para a expansão contra outras unidades estatais sejam dirigidos, em um segundo momento, para a segurança interna e para o reforço de um poder central que impõe cada vez mais a coesão social através de mecanismos centralizadores mais sofisticados. A Guerra e a Paz, em uma perspectiva complementar, convertem-se em um jogo de xadrez político do qual saem frequentemente 
fortalecidos os mecanismos centralizadores. A origem medieval dos estados modernos repousa, em parte, no fortalecimento deste circuito: guerra, paz, tributação centralizada, monopólio da violência estatal - esta última tanto dirigida para assegurar ou expandir fronteiras, como para impor uma organização interna do espaço social.

xxii É um pouco perturbadora, ou no mínimo intrigante, a comparação entre os últimos capítulos de $O$ Príncipe e o 'Capítulo 55' do Livro I dos Discursos dobre a Primeira Década de Tito Lívio. Fica-se com a impressão de que, no Príncipe, Maquiavel exorta a unificação sob um regime de principado, como uma espécie de "mal necessário", pois caso contrário a península Itálica continuará na mão dos estrangeiros, ou dos "bárbaros", como ele os chama no capítulo XXVI. Não obstante, no referido capítulo dos Discursos sobre a Primeira Década de Tito Lívio, Maquiavel opõe valorativamente algumas das repúblicas italianas "livres" contra dois dos reinos centralizados de sua época - a Espanha e a França - assim como desvaloriza os demais principados italianos. Claude Lefort (1979) assim resume este passo: "Maquiavel estabelece um contraste entre, de um lado, as cidades alemãs que lhe parecem oferecer o modelo moderno dos povos livres - aos quais se aparentam as repúblicas de Florença, de Veneza, de Siena e de Luca, nas quais a liberdade se mantém ou sobrevive - e, de outro lado, os reinos da França e Espanha e todos os principados da Itália. A oposição se apresenta como aquela dos estados sadios aos estados corrompidos” (LEFORT, 1990, p.147).

xxiii "Vemos, de fato, que os homens, com intuito de atingir as metas visadas - a saber, glória e riquezas conduzem-se de maneiras diversas: um com cautela, outro com arrebatamento; este com violência, aquele com ardis; um com paciência, outro com impaciência ... e todos, mediante esses modos distintos, podem atingir as metas visadas. Vê-se também que, de duas pessoas cautelosas, uma atinge a meta, a outra não. E vê-se, analogamente, que duas pessoas podem ser bem sucedidas mediante duas maneiras de conduta distintas, sendo uma cautelosa e a outra arrebatada. Isto se explica tão somente pela natureza dos tempos que se ajusta ou não à sua maneira de agir" (MAQUIAVEL, 2000, p.171). Este esclarecimento de que não há uma Virtu fixa, idealizada - como parecem propor os espelhos de príncipe tradicionais - coloca mais uma vez Maquiavel no centro de uma abordagem realista. É preciso avaliar a situação - o movimento da Fortuna - e, a partir daí, tirar partido da sua Virtu e do conhecimento sobre como e quando usá-la. Maquiavel propõe uma nova ética, flexível ao enfrentamento das circunstâncias.

xxiv A Rainha Cristina, da Suécia (1626-1689), à maneira do que faria Napoleão Bonaparte mais de um século mais tarde, também elaborou as suas próprias notas ao Príncipe de Maquiavel. O rei prussiano Frederico II, tal como já destacamos, elabora o seu texto-contra-texto intitulando-o Anti-Maquiavel. O ditador italiano Benito Mussolini irá considerar $O$ Príncipe de Maquiavel como um manual para políticos e governantes, reinterpretando-o em termos fascistas e dedicando a isto um texto específico, que foi por ele chamado de Prelúdio a Maquiavel (1924). Antonio Gramsci - assimilando a figura do príncipe moderno ao Partido que deveria encaminhar a revolução - toma a análise da perspectiva introduzida pelo autor florentino como um objeto de estudo fundamental no seu ensaio Notas sobre Maquiavel, a Política e o Estado Moderno (1949). A figura do Príncipe, conforme se vê nesta análise, deixa de ser individual e conflui para uma entidade coletiva.

${ }^{\mathrm{xxv}}$ De his quae optimus princibus agenda sunt (1521). Cfe. FIRPO, 1970, p.349.

${ }^{x x v i}$ A primeira versão do Index Librorum Prohibitorum foi promulgada pelo papa Paulo IV, em 1559, e uma versão revista desta lista foi autorizada pelo Concílio de Trento. A última edição do Índex foi publicada em 1948, mas só em 1966 a Igreja Católica aboliu formalmente o índice, com o papa Paulo VI (1897-1978).

xxvii Já como papa, aliás, no frigir dos acontecimentos de 1527 Clemente VII havia sido levado prisioneiro pelas tropas da Espanha e do Sacro-Império Romano-Germânico, que haviam invadido Roma a mando de seu imperador, Carlos V (o qual, além de ser Imperador desde 1519, acumulava também o título de Rei da Espanha desde 1516). A captura do papa Clemente VII - um dos Médicis - ajudara inclusive na derrubada do governo florentino por eles controlado, abrindo caminho para a revolta republicana que depôs em 1527 o cardeal Silvio Passerini, representante do papa Clemente VII no governo da cidade. Na verdade, ainda haveria uma nova oscilação de poder, pois em 1530 o papa Clemente VII conseguiu firmar um acordo com o Imperador Carlos V e a República de Florença foi subjugada ainda mais uma vez, com nova restauração do poder dos Médici e a instalação de Alexandro de Médici no governo em 1531. Este não tardaria a ser nomeado Duque hereditário de Florença, de modo que a história do domínio dos Médici sobre Florença segue adiante, mas sempre contraposta às pressões da oposição republicana. Maquiavel, contudo, não veria estes acontecimentos, pois veio a falecer no mesmo ano da revolta republicana (1527). 
xxviii É particularmente interessante observar que - neste verbete para a célebre Enciclopédia de 1751 - Diderot começa por definir depreciativamente o "maquiavelismo", neste caso utilizando-o como uma palavra que se vê derivada da expressão negativa "maquiavélico" e não da expressão positiva "maquievaliano". Para tal, Diderot delineia o "maquiavelismo" como "uma espécie de política detestável que se pode definir com duas palavras: é a arte de tiranizar, cujos princípios Maquiavel difundiu em suas obras" (DIDEROT, 2015, p.231). No entanto, com a leitura subsequente do verbete, percebe-se com clareza que o maquiavelismo seria a "política detestável" que já existia independente de Maquiavel, e que este apenas fizera o favor de explicitála. Neste caso, Maquiavel seria uma espécie de médico que identificara uma doença, de modo a que se pudesse combatê-la - daí decorrendo que, tal como ocorre nestes casos, a doença terminou por ser batizada com o nome do seu descobridor pra homenagear a sua notável contribuição para a ciência.

xxix Quando começou a escrever $O$ Príncipe em 1513, tarefa da qual se desincumbe em algumas semanas - ou ao menos em alguns meses, segundo Hans Baron (1961, p.249-251) - Maquiavel já vinha escrevendo os Discursos sobre a Primeira Década de Tito Lívio. Ele interrompe esta escrita - uma atenta reflexão sobre a República - para escrever em apenas um tempo relativamente curto o pequeno livro que o tornaria célebre. Um sinal disso é indicado no Capítulo II de $O$ Príncipe, no qual o autor florentino, depois de afirmar que existem basicamente dois troncos de formas de governo - as Repúblicas e os Principados - declara que neste seu opúsculo denominado $O$ Príncipe irá apenas se dedicar aos principados, pois já vinha se dedicando à reflexão sobre a República em uma obra anterior (MAQUIAVEL, 2000, p.47). Depois da elaboração de $O$ Príncipe, Maquiavel retoma os Discursos, obra mais meticulosa à qual se dedica até 1521. Esta, como já assinalamos, só seria publicada por completo em 1531, postumamente.

xxx $\mathrm{O}$ pessimismo em relação à natureza humana acompanha estas duas obras, tornando-se uma nota característica do acorde teórico de Maquiavel. Em O Príncipe, já indicamos trechos nos quais se expressa a ideia de que os homens são naturalmente maus. Nos Discursos sobre a primeira década de Tito Lívio, encontramos uma passagem significativa: "[é preciso partir do princípio] de que todos os homens são maus, estando dispostos a agir com perversidade sempre que haja ocasião" (MAQUIAVEL, 1982, p.29). 